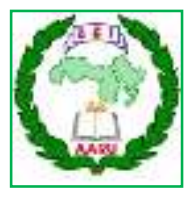

Arab Univ. J. Agric. Sci., Ain Shams Univ., Cairo, Egypt

29(1), 211 - 226, 2021

Website: http://ajs.journals.ekb.eg

DOI: 10.21608/ajs.2021.55603.1323

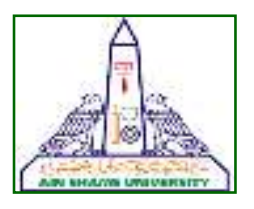

\title{
Performance Evaluation of Solar Pump for Landscape Irrigation System
}

\author{
Rofida HMR Al-Ahwal ${ }^{*}$, Mahmmoud M Hegazi ${ }^{1}$, Mohammed Hewidy ${ }^{2}$, \\ Osama MA Bedair ${ }^{2}$ \\ 1- Agric Engineering Dept, Fac of Agric, Ain Shams Univ, P.O. Box 68, Hadyek Shoubra, \\ 11241, Cairo, Egypt \\ 2- Horticulture Dept, Fac of Agric, Ain Shams Univ, P.O. Box 68, Hadyek Shoubra, \\ 11241, Cairo, Egypt \\ * Corresponding author: rofida@agr.asu.edu.egorcid.org/0000-0002
}

Received 31 January, 2021

Accepted 10 March, 2021

\begin{abstract}
Experiments were performed at a private garden in Al-Qaddbah, Al-Gharbia Governorate, Egypt. The latitude and longitude of the experiment site are $30^{\circ} 56^{\prime} 37^{\prime \prime} \mathrm{N}$ and $30^{\circ} 47^{\prime} 01^{\prime \prime}$ $\mathrm{E}$, respectively, and the altitude equals $30 \mathrm{~m}$, at the 2019 season, the total landscape area $(13.5 \mathrm{~m} \times 9 \mathrm{~m})$ was divided into 6 treatments each of an area $\left(20.25 \mathrm{~m}^{2}\right)$, three plots were operated using solar system while the other three plots were operated using electric system. The irrigation systems were similar, 4 multi-stream sprayers, $\left(90^{\circ}\right)$ and the distance between the sprayers was $\left(4.5^{*} 4.5 \mathrm{~m}\right)$, different operating times were applied on each plot, under local climatic and working conditions. All the plots were planted with turfgrass (Passpalm10). The obtained results show, at solar energy powered system, uniformity coefficient increased from $(65 \%-75 \%)$ at operating time $(10-30 \mathrm{~min})$, then it decreased during operating time (40 $60 \mathrm{~min}$ ), while at electric energy powered system the averages of the uniformity coefficient were $(76 \%-80 \%)$, at operating time (10 - 40 $\mathrm{min}$ ), while at operating time (45 - $60 \mathrm{~min})$ the uniformity coefficient decreased to $(75 \%)$, due to the silt clogging in the sprayers' filters. The energy saving reached $(63 \%)$ with solar
\end{abstract}

energy operation rather than electric energy operation in the summer season. The least total cost was $\left(351 \mathrm{~L} . \mathrm{E} / \mathrm{m}^{2} /\right.$ year $)$ at the landscape area $\left(\mathrm{A}_{3} 60.75 \mathrm{~m}^{2}\right)$, which was irrigated on 3 cycles per day to give the highest uniformity coefficient $(75 \%)$. When operating the solar batteries at full charge 3 - 4 times for a plot area of $\left(20.25 \mathrm{~m}^{2}\right)$. The hydraulic power obtained was $(17.86-26.74 \mathrm{~W})$, the sprayer radius was $(5.3-5.8 \mathrm{~m})$, at an average pressure of $(1.9-2.5$ bar $)$ which gave the best uniformity coefficient. The turf quality index was higher using electric motor rather than solar motor.

Keywords: Solar energy; Electric energy; Unite area; landscape irrigation; Battery cycle.

\section{Introduction}

According to U.S. Energy Information Administration (USEIA). The averages of solar radiation in Egypt are 5 and more than 8 $\mathrm{kWh} / \mathrm{m}^{2}$ of annual daily direct solar radiation, while the annual direct normal solar irradiance ranges between $(2,300-4,000) \mathrm{kWh} / \mathrm{m}^{2}$, with 9-11 hr/day of sunlight, and few cloudy days throughout the year, (USEIA 2014). 
For renewable energy, Egypt is treated as a country of a suitable environment to meet a huge amount of its energy requirements by using wind and solar power. Due to its location, topography, and climate, Egypt is one of the world's best which is suitable for setting up wind and solar energy systems. But, the possibility of using renewable energy is limited by Egypt's energy mix, African Development Bank (AfDB 2012) and (Bahgat 2013).

In Egypt, photovoltaic systems are suitable for remote areas. According to New and Renewable Energy Authority (NREA), photovoltaic technologies are used for irrigation water pumping in recently reclaimed lands. The capacity of Egypt's photovoltaic systems placed presently is close to $5 \mathrm{MW}$ peak, (Comsan 2010).

The advantages of the solar pumps are being capable of functioning under imperfect sunlight radiation conditions. The use of solar water pumps operate on varying voltage and current. However, pumps that operate using electric power need enough power to pump a large quantity of water in a short time. Solar pumps on the other hand pump less quantities of water for a longer operation time and would require less energy, (Malak 2016).

In Egypt, solar photovoltaic water pumping systems (SPWPSs) are used for water pumping in the agriculture sector. The price of the water pumped by solar systems is much less than that of water pumped using conventional diesel or traditional electrical pumps. SPWPSs are more effective than other irrigation systems during daylight, (Gopal et al 2013).

Because of the frequent electricity cut, also the solar radiation is at its peak during the summer season, which means there is unutilized solar power, the solar powered system needs a power of 24 volts which is acquired by a photovoltaic cell, the longrun cost is inexpensive, so the experiment is carried out. The objectives of this study are calibrating solar and electric pumps $(\mathrm{Q}-\mathrm{H})$, identifying the best irrigated landscape area to match the solar powered system per day, specifying the best operation time of irrigation to match the turf irrigation requirements, determining the best operation time for DC battery charging to give full power to operate the landscape irrigation system, calculating the annual cost for the solar and electric powered system, and indicating the quality index (color, density, and ground cover \%) for turfgrass (Paspalum 10) under the solar and electric powered system.

\section{Materials and Methods}

\subsection{Experiment location}

Experiments were performed at a backyard area (private garden) in Al-Qaddbah, Al-Gharbia Governorate, Egypt. The latitude and longitude of the experiment site were $30^{\circ} 56^{\prime} 37^{\prime \prime} \mathrm{N}$, $30^{\circ} 47^{\prime} 01^{\prime \prime} \mathrm{E}$, respectively with altitude equals $30 \mathrm{~m}$, to evaluate the best utilization of solar and electric pump for irrigating landscape area, during 2019 season.

\subsection{Field experiment layout and design}

The area of the experiment was $\left(121.5 \mathrm{~m}^{2}\right)$, divided into 6 plots, each plot $(4.5 \mathrm{~m} \times 4.5 \mathrm{~m})$ for spray irrigation. The 6 plots were planted with turfgrass (Passpalm 10). Three plots were irrigated using solar pump, while the three other plots were irrigated using electric pump under local climatic and working conditions as shown in Figs 1, 2, and 3.

\subsection{Storage tank}

A 500- liters tank made of plastic was used to store water as the inlet source for the irrigation system which provided stable zero pressure.

\subsection{Irrigation systems}

Spray Irrigation (SI): 4 multi-stream sprayers, $\left(90^{\circ}\right)$ for each plot. Sprayers used in this experiment for landscape with nozzle discharge of $0.071 \mathrm{~m}^{3} / \mathrm{h}$, at the head of $20 \mathrm{~m}$, average precipitation rate of $12 \mathrm{~mm} / \mathrm{h}$, and radius of $4.5 \mathrm{~m}$, the sprayers' filters of $150 \mu$ to irrigate turfgrass (Paspalum 10), as shown in Figs 4, 5, 6 and 7. 
13.5

\begin{tabular}{|c|c|c|c|}
\hline \multirow[t]{6}{*}{4.5} & $S A_{1} T_{1}$ & $\mathrm{SA}_{1} \mathrm{~T}_{2}$ & $\mathrm{SA}_{1} \mathrm{~T}_{3}$ \\
\hline & $S A_{2} T_{1}$ & $\mathrm{SA}_{2} \mathrm{~T}_{2}$ & $\mathrm{SA}_{2} \mathrm{~T}_{3}$ \\
\hline & $S A_{3} T_{1}$ & $\mathrm{SA}_{3} \mathrm{~T}_{2}$ & $\mathrm{SA}_{3} \mathrm{~T}_{3}$ \\
\hline & $\mathrm{E} \mathrm{A}_{1} \mathrm{~T}_{1}$ & $\mathrm{E} \mathrm{A}_{1} \mathrm{~T}_{2}$ & $\mathrm{E} \mathrm{A}_{1} \mathrm{~T}_{3}$ \\
\hline & $\mathrm{E} \mathrm{A}_{2} \mathrm{~T}_{1}$ & $\mathrm{E} \mathrm{A}_{2} \mathrm{~T}_{2}$ & $\mathrm{E} \mathrm{A}_{2} \mathrm{~T}_{3}$ \\
\hline & $\mathrm{EA}_{3} \mathrm{~T}_{1}$ & $\mathrm{EA}_{3} \mathrm{~T}_{2}$ & $\mathrm{E} \mathrm{A}_{3} \mathrm{~T}_{3}$ \\
\hline S: $s$ & lar syst & & ectric \\
\hline A: & nit area & & eration \\
\hline
\end{tabular}

Fig 1. Layout of irrigated plot area by solar and electric pumps by random sectors

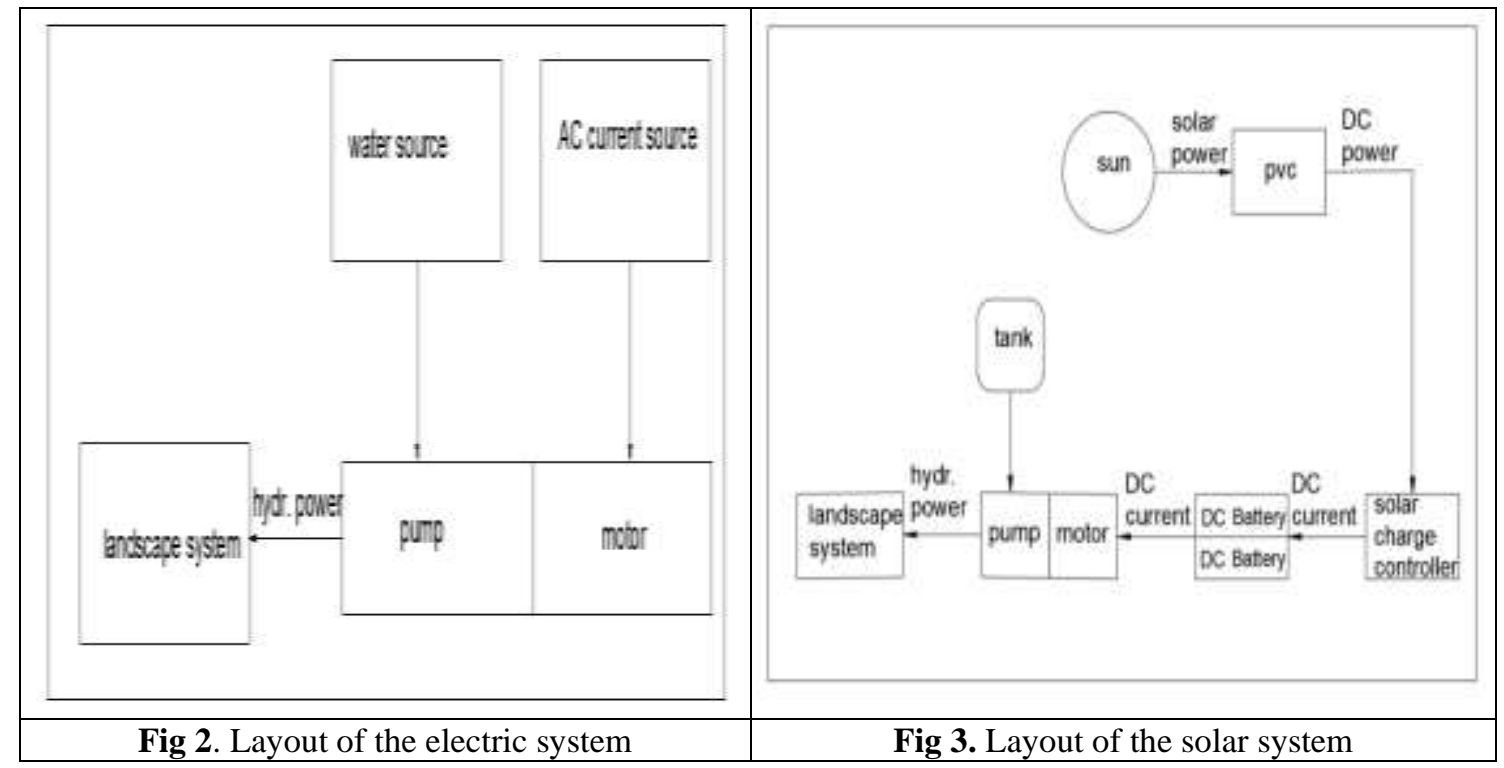




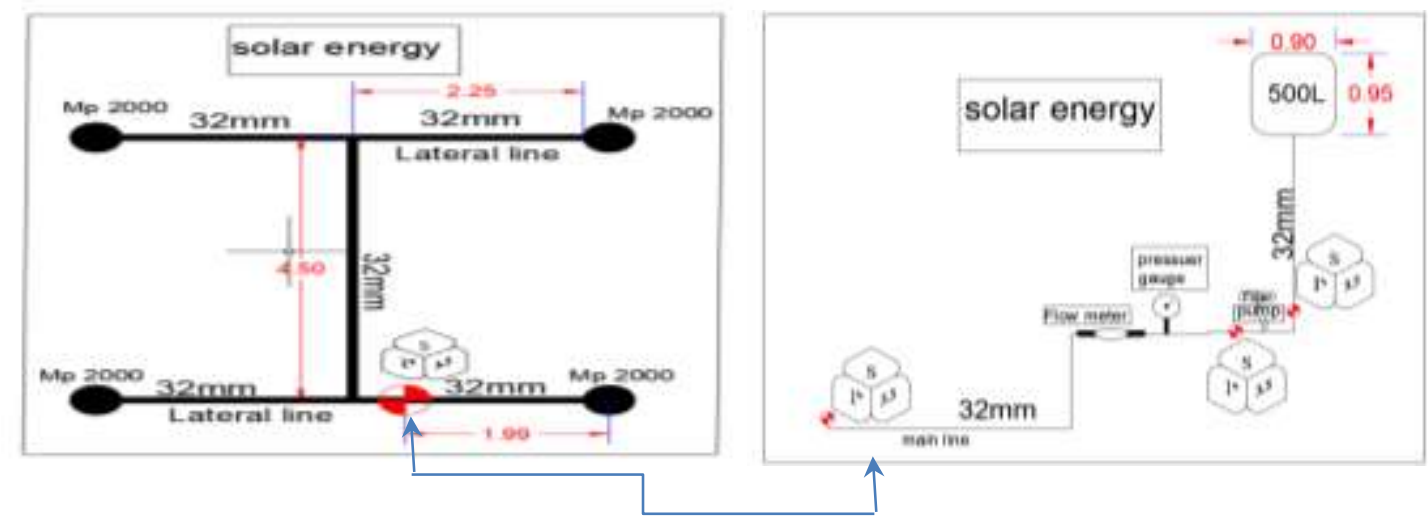

Figs 4 and 5. Layout of the irrigation system for the solar-powered plot

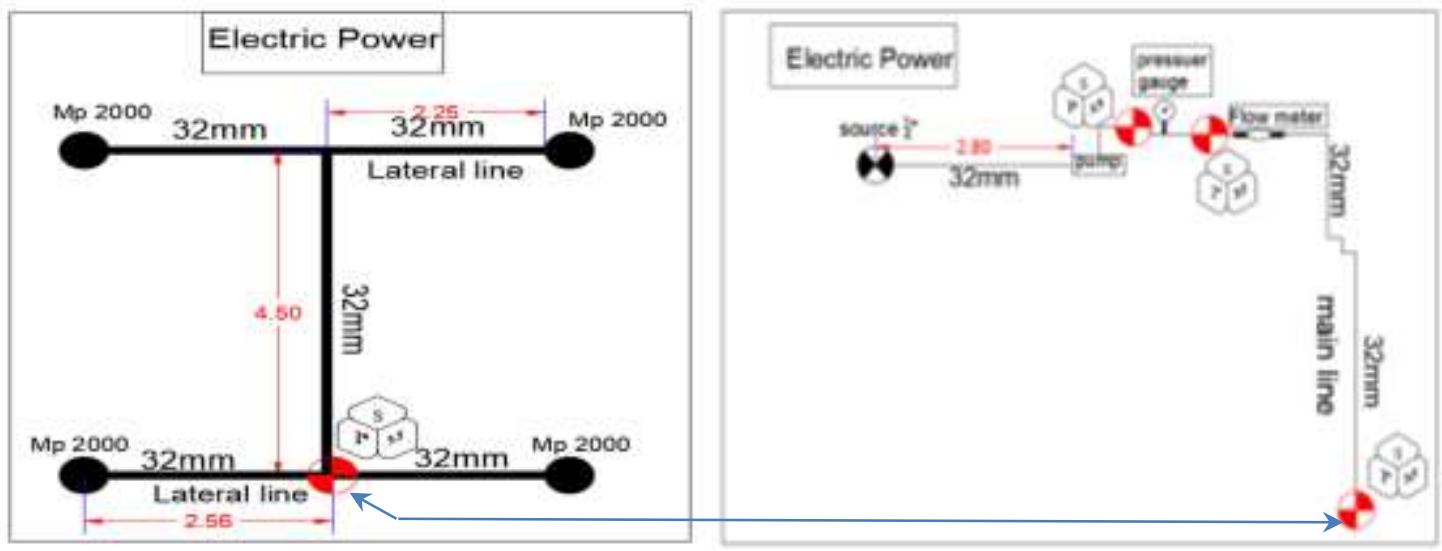

Figs 6 and 7. Layout of the irrigation system for the electric-powered plot

The specifications of the multi-stream sprayers are presented in Table 1.

\subsection{Treatments}

\subsubsection{Photovoltaic cell, charge controller and the solar system specifications}

The specifications of the photovoltaic module and electrical data (STC) are presented in Table 2.

While the charge controller was used to adjust the voltage and current from the solar arrays to the battery to prevent overcharging and also overdischarging.

The specifications of the charge controller used in this experiment are presented in Table 3.

\subsubsection{Dc batteries}

Two batteries were used to operate the system connected parallel, (24 Volt - 12 Ampere). The specifications of the batteries are presented in Table 4.

\subsubsection{Dc motor and pump}

24 volt, 4.5GPM/17.0LPM. The pump supplies high volume water flow with lower pump cycling. It can be used with a tank water system. It can supply up to $1022 \mathrm{~L} / \mathrm{h}$. It has a builtin pressure switch, which automatically switches on/off the pump when the valve is opened and closed.

The specifications of both the Dc pump and motor are presented in Table $\mathbf{5}$. 
Table1. Specifications of the multi-stream sprayers

\begin{tabular}{|c|c|c|c|c|c|c|c|}
\hline $\begin{array}{c}\text { Pressure } \\
\text { Bar }\end{array}$ & 1.7 & 2.0 & 2.5 & 2.8 & 3.0 & 3.5 & 3.8 \\
\hline $\begin{array}{c}\text { Radius } \\
\mathrm{m}\end{array}$ & 5.2 & 5.5 & 5.8 & 6.1 & 6.4 & 6.4 & 6.4 \\
\hline $\begin{array}{c}\text { Flow } \\
\mathrm{m}^{3} / \mathrm{hr}\end{array}$ & 0.07 & 0.07 & 0.09 & 0.09 & 0.09 & 0.10 & 0.11 \\
\hline $\begin{array}{c}\text { Precip } \\
\mathbf{\mathrm { mm }} / \mathrm{hr}\end{array}$ & 12 & 11 & 12 & 11 & 10 & 11 & 12 \\
\hline
\end{tabular}

Table 2. Technical specifications of the photovoltaic module and electric data

\begin{tabular}{|c|c|}
\hline $\begin{array}{c}\text { Length x width x height } \\
{[\mathbf{m m}]}\end{array}$ & $\mathbf{1 6 5 0}^{* 9990} * \mathbf{5 0 m m}$ \\
\hline Number of cells & 60 poly cells \\
\hline Cell material & Polycrystalline \\
\hline Nominal Peak Power $\left(\mathrm{P}_{\mathrm{mpp}}\right)$ & $240 \mathrm{~W}$ \\
\hline Open-Circuit Voltage $\left(\mathrm{V}_{\mathrm{oc}}\right)$ & 36.2 Volt \\
\hline Short-Circuit Current $\left(\mathrm{I}_{\mathrm{sc}}\right)$ & $8.88 \mathrm{Amper}$ \\
\hline Temperature Range & $-40^{\circ} \mathrm{C}:+90^{\circ} \mathrm{C}$ \\
\hline
\end{tabular}

Table 3. Specification of the charge controller

\begin{tabular}{|c|c|}
\hline Category & 12V-20Ampere \\
\hline $\begin{array}{c}\text { To adapt to the battery } \\
\text { voltage }\end{array}$ & $\begin{array}{c}12 \mathrm{~V} / 24 \text { Volt } \\
\text { Automatically identify }\end{array}$ \\
\hline $\begin{array}{c}\text { The maximum output } \\
\text { current }\end{array}$ & 20Ampere \\
\hline
\end{tabular}

Table 4. Specifications of the Dc batteries

\begin{tabular}{|c|c|}
\hline $\begin{array}{c}\text { Nominal } \\
\text { Voltage }\end{array}$ & 12Volt \\
\hline $\begin{array}{c}\text { Nominal } \\
\text { Capacity } \\
(20 \mathrm{HR})\end{array}$ & $12.0 \mathrm{AH}$ \\
\hline Terminal & $\mathrm{T} 2$ \\
\hline Self Discharge & $\begin{array}{c}\text { It can be stored for up to } 6 \\
\text { months at 250 C(770F). } \\
\text { For higher temperatures, the time } \\
\text { interval will be shorter. }\end{array}$ \\
\hline
\end{tabular}

Table 5. Specification of the Dc pump and motor

\begin{tabular}{|c|c|}
\hline \multicolumn{2}{|c|}{ Motor } \\
\hline Max.Amp Draw & 15.0 Ampere \\
\hline power & 144 Watts/h \\
\hline Type & $\begin{array}{c}\text { P Champer positive dis- } \\
\text { placement diaphragm } \\
\text { pump, self-priming, able } \\
\text { of being run dry }\end{array}$ \\
\hline Control Type & $\begin{array}{c}\text { Pressure switch \& By- } \\
\text { pass control }\end{array}$ \\
\hline Re-start Pressure & $\begin{array}{c}\text { Shut-off Pressure 2.8 } \\
\text { bar : 2 bar ( } \pm \text { 0.3 bar) }\end{array}$ \\
\hline Inlet/Outlet Ports & 3/4" QUICK AT- \\
& TACH \\
\hline
\end{tabular}

\subsubsection{The electrical system, AC motor and pump specifications}

The pump was not self-priming, so on the system, it is loaded directly to the entrance pipe of water, the valve was switched on before starting the motor to replace all the air in the pipe before the pump, the pressure was stabilized by loading a valve after the pump to get rid of the excess pressure.

The specifications of both the AC pump and motor are presented in Table 6.

\subsection{Measurements and calculations}

Calibrate solar and electric pumps in the site by measuring different flow and pressure of solar and electric pumps, was done to find the best operating point for solar and electric operating systems.

2.6.1 Determine pump discharge and uniformity coefficient spray at different operation times for solar and electric energy.

2.6.2 Calculate evapotranspiration at different months through the year 2019, from the Central Laboratory for Agricultural Climate, to achieve the best water requirements and low power usage for the landscape plot area. 
Table 6. Specifications of Ac motor and pump

\begin{tabular}{|c|c|c|c|c|}
\hline Model & $\begin{array}{c}\text { Maximum Capacity } \\
\text { l/min }\end{array}$ & $\begin{array}{c}\text { Maximum Head } \\
(\mathbf{m})\end{array}$ & $\begin{array}{c}\text { Maximum Suc. Lift } \\
(\mathbf{m})\end{array}$ & $\begin{array}{c}\text { Power } \\
\text { (HP) }\end{array}$ \\
\hline QB60 & 26 & 30 & 9 & 0.5 \\
\hline
\end{tabular}

2.6.3 Determine the best total water usage and power usage for landscape plot areas for every season under solar and electric energy sources.

2.6.4 Determine the effect of the different running times of solar pump on the uniformity coefficient of the sprayers for the landscape plot area.

2.6.5 Determine the best uniformity coefficient of sprayres, maximum plot area and the best operating time at different battery cycles.

2.6.6 Determine the turf quality index including (color, density, and ground cover \%), which was affected by the power source used to operate the landscape area, as the variance of the operating pressure influenced the uniformity coefficient of water, which affected the quality index.

\subsection{Coefficient of water uniformity}

Christiansen's uniformity coefficient was first used to present a uniformity coefficient to the sprinkler system (Karmeli 1978). It was used by researchers worldwide as a proven standard to represent water distribution uniformity (Karmeli 1978; Topak et al 2005):

$$
\begin{gathered}
C U=100 *\left\{1-\frac{\sum\left|x-x^{-}\right|}{n x^{-}}\right\}----(1) \\
\text { Where: }
\end{gathered}
$$

$\mathrm{CU}=$ The Christiansen's uniformity coefficient in \%;

$\mathrm{x}=$ Numerical deviation of individual observation from average application rate, $\mathrm{mm}$; $\mathrm{x}^{-}=$Mean of collectors amount in $\mathrm{mm}$; and $\mathrm{n}=$ Number of catch cans.

\subsection{Plant water requirement}

Plant water requirement was calculated according to the climate data (Costello et al 1993):

$$
\mathrm{PWR}=\mathrm{ET}_{\mathrm{o}} \times \mathrm{K}_{\mathrm{L}}-----(2)
$$

Where:

PWR $=$ Plant water requirement $(\mathrm{mm} /$ season $)$. $\mathrm{ET}_{\mathrm{o}}=$ Reference ET based on cool-season grass (mm /season).

$\mathrm{K}_{\mathrm{L}}=$ Landscape coefficient (dimensionless).

\section{Climatic data at Al-Gharbia governorate sites}

The average $\mathrm{ET}_{\mathrm{o}}$ during the months of the experiments in 2019 from the Central Laboratory for Agricultural Climate (CLAC) for AlGharbia Governorate sites, shown in Table 7.

A landscape coefficient KL was suggested by (Awady et al 2003; IA 2009), it was calculated by the following formula:

$$
\mathrm{K}_{\mathrm{L}}=\mathrm{K}_{\mathrm{s}} \times \mathrm{K}_{\mathrm{mc}} \times \mathrm{K}_{\mathrm{d}}-----(3)
$$

Where:

$\mathrm{K}_{\mathrm{L}}=$ Landscape coefficient (dimensionless);

$\mathrm{K}_{\mathrm{s}}=$ Adjustment factor representing characteristics for a particular plant species (dimensionless);

$\mathrm{K}_{\mathrm{mc}}=$ Adjustment factor for microclimate influences upon the planting (dimensionless); and

$\mathrm{K}_{\mathrm{d}}=$ Adjustment factor for plant density (dimensionless), Table 8. 

Irrigation System

Table 7. The average $\mathrm{ET}_{\mathrm{o}}$ in the 2019 season for Al-Gharbia Governorate

\begin{tabular}{|c|c|c|c|c|c|c|c|c|c|c|c|c|}
\hline Month & Jan & Feb & Mar & Apr & May & Jun & Jul & Aug & Sep & Oct & Nov & Dec \\
\hline $\mathrm{T}_{\text {max }}^{\circ}$ & 26.2 & 29.5 & 40.5 & 40 & 46.6 & 47.4 & 43.2 & 46.1 & 42.1 & 37.9 & 30.2 & 28.4 \\
\hline $\begin{array}{c}\text { Average } \mathrm{ET}_{\mathrm{o}} \\
(\mathrm{mm})\end{array}$ & 1.4 & 2.2 & 3.3 & 4.1 & 5.4 & 5.8 & 6 & 8 & 7.2 & 6.5 & 3.5 & 2 \\
\hline
\end{tabular}

Table 8. Species factor $\left(K_{s}, K_{m c}\right.$, and $\left.K_{d}\right)$ for different plant types. Density factor $(\mathrm{Kd})$ for different plant types.

\begin{tabular}{|c|c|c|c|}
\hline Vegetation & High & Average & Low \\
\hline Turfgrass & 1 & 1 & 0.6 \\
\hline
\end{tabular}

\begin{tabular}{|l|c|c|c|}
\hline Vegetation & High & Average & Low \\
\hline \multicolumn{3}{|c|}{ Species factor (Ks) } \\
\hline $\begin{array}{l}\text { Warm season } \\
\text { turfgrass }\end{array}$ & 0 & 0.6 & 0 \\
\hline $\begin{array}{l}\text { Cool Season } \\
\text { Turfgrass }\end{array}$ & 0 & 0.8 & 0 \\
\hline
\end{tabular}

\begin{tabular}{|l|c|c|c|}
\hline \multicolumn{4}{|c|}{ Microclimate factor $(\mathbf{K m c})$} \\
\hline Turfgrass & 1.2 & 1 & 0.8 \\
\hline \multicolumn{4}{|c|}{ Density factor $(\mathbf{K d})$} \\
\hline Turfgrass & 1 & 1 & 0.6 \\
\hline
\end{tabular}

(Awady et al 2003; IA 2009).

\subsection{Irrigation Run Time for the operation}

Irrigation run time is the period that a zone valve is activated as required to achieve the water requirement for an irrigation operation time. It is usually defined in minutes. The base run time for the operation time (RT base) relies on the base irrigation water requirement for the operation time (IWR base) and the precipitation rate (PR) of the station/zone in applying the water:

$$
\mathrm{RT}=\mathrm{IWR} \times(60 / \mathrm{PR})-----(4)
$$

Where:

$\mathrm{RT}=$ Base run time (minutes) for the operation; IWR $=$ Base irrigation water requirement $(\mathrm{mm})$ for the operation; and $\mathrm{PR}=$ Precipitation rate of station/zone $(\mathrm{mm} / \mathrm{h})$.

\subsection{Hydraulic horsepower (water HP)}

The mechanical power of a hydraulic flow is the product of the fluid flow rate, by the head at which it is transferred. The water horse power was calculated according to (El-Gindy 2007) as follows:

$$
\text { Water } \mathrm{HP}=(\mathrm{QH} / 75)^{*} 0.746-----(5)
$$

Where:

Water HP $=$ Water horse power $(\mathrm{kW})$;

$\mathrm{Q}=$ Discharge (Lps) ; and

$\mathrm{H}=$ Pressure head $(\mathrm{m})$.

$$
\text { Break Hp = Water HP / E -----(6) }
$$

Where:

$\mathrm{E}=$ Motor Efficiency, (\%).

\subsection{Quality index}

Turf quality index represents color, density, and ground cover percent for lawn plant (Paspalum 10) as shown in Table 9, according to (Khaseeva 2013).

Table 9. Turf quality index

\begin{tabular}{|c|c|c|c|}
\hline $\begin{array}{c}\text { Type of } \\
\text { turf }\end{array}$ & Color & $\begin{array}{c}\text { Density } \\
\left(\mathbf{p c s} / \mathbf{m}^{\mathbf{2}}\right)\end{array}$ & $\begin{array}{c}\text { Ground } \\
\text { cover\% }\end{array}$ \\
\hline $\begin{array}{c}\text { Paspa- } \\
\text { lum 10 }\end{array}$ & $0-9$ & $0-9$ & $1-9$ \\
\hline
\end{tabular}

Where,

1. Color: a 0 -to- 9 scale, where $0=$ brown, (dead turf); 6 =acceptable quality for home lawn; and $9=$ optimum color (dark green). 
2. Density $\left(\mathrm{pcs} / \mathrm{m}^{2}\right)$ : summer density (1=low, $9=$ high), turf density was measured instrumentally and expressed in the number of tillers per unit area $\left(\mathrm{pcs} / \mathrm{m}^{2}\right)$, high ratings (> 10000 shoots $\left./ \mathrm{m}^{2}\right), 9$ provided moderate density (6000 to 10000 shoots $/ \mathrm{m}^{2}$ ) and 4 demonstrated low ratings $\left(<6000\right.$ shoots $\left./ \mathrm{m}^{2}\right)$.

3. Ground cover\%: ground cover $(1=0 \%, 9=$ $100 \%$ cover).

\subsection{Cost analysis}

Annual total cost $=$ Total initial costs + Total operational costs

Where,

Total initial costs, L.E./year $=[\mathrm{a}]+[\mathrm{b}]$.

i.e., Pumps and installation, L.E [a] + additional infrastructure, L.E [b].

Total operational costs, L.E./year $=[\mathrm{h}]+[\mathrm{i}]$ $+[\mathrm{s}]$.

i.e., Energy costs per year, L.E/year [h] + water consumption costs per year, L.E/year [i] + maintenance per year [s].

Where,

[a]: Pumping cost (L.E. $\left./ \mathrm{m}^{3}\right)$.

[i]: Water consumption $\left(\mathrm{m}^{3} / \mathrm{m}^{2} /\right.$ year $)$.

[a] $+[\mathrm{b}]$ : Initial cost (L.E.), for the present value of the equipment irrigation system.

[s]: Maintenance costs, taken as $10 \%$ of its initial cost (L.E./year).

Years of working life expectancy (20 years).

\section{Results and Discussion}

\subsection{Performance of solar and electric pumps in site}

Results illustrated in Fig 8 showed that the operation head increased when the discharge decreased for both solar and electric pumps for a plot area of $\left(20.25 \mathrm{~m}^{2}\right)$. The optimum operation point for the solar pump which gives the maximum efficiency resulted from the relation between the flow and the head at the point of head of $(17 \mathrm{~m})$ and a discharge of $(800 \mathrm{~L} / \mathrm{h})$, the optimum operating point for the electric pump gives the maximum efficiency at the point of $(17 \mathrm{~m})$ and a discharge of $(1200 \mathrm{~L} / \mathrm{h})$.

\subsection{The capacity of water requirement land- scape plot area at different interval times}

Fig 9, represents that the maximum discharge value for the solar pump was $(0.29$ $\mathrm{m}^{3} / \mathrm{h}$ ) at an operation time of irrigation $60 \mathrm{~min}$, while the minimum discharge value was $(0.06$ $\mathrm{m}^{3} / \mathrm{h}$ ) at an operation time of irrigation of 10 min to provide the water required for the landscape plot, the system should be operated for $45 \mathrm{~min}$, at the discharge of solar pump of $(0.23$ $\mathrm{m}^{3} / \mathrm{h}$ ). Also, the maximum discharge value for the electric pump was $\left(0.32 \mathrm{~m}^{3} / \mathrm{h}\right)$ at an operation time of irrigation of $60 \mathrm{~min}$, while the minimum discharge value was $\left(0.05 \mathrm{~m}^{3} / \mathrm{h}\right)$ at an operation time of irrigation of $10 \mathrm{~min}$, to provide the water required for landscape plot, the system should be operated for $45 \mathrm{~min}$, at the discharge of electric pump of $\left(0.24 \mathrm{~m}^{3} / \mathrm{h}\right)$.

3.3 The relation between the uniformity coefficient at different operation irrigation times

Data illustrated in Fig 10 indicated that using the solar pump, the uniformity coefficient increased from ( 65 to $75 \%$ ) by increasing the operation time of irrigation from 10 to $30 \mathrm{~min}$. Then it decreased after that by increasing the operation time of irrigation from 40 to $60 \mathrm{~min}$ as a result of the decrease of the power in the batteries. Also, the coefficient of the uniformity increased from (76 to $80 \%$ ) by increasing the irrigation time from 10 to $40 \mathrm{~min}$. Then it decreased to $(75 \%)$ when the irrigation time increase from 45 to $60 \mathrm{~min}$, using an electric pump, due to the silt clogging in the filters of the sprayers.

\subsection{The relation between consumptive total power usages for a landscape plot area per season under solar and electric energy}

Data illustrated in Fig 11 showed that the highest power usage for the solar pump was during summer at a value of $(9.90 \mathrm{~kW} / \mathrm{season})$, while the lowest power usage was during winter at a value of (1.83 kW/season). Also, the highest power usage for the electric pump was during summer at a value of $(27 \mathrm{~kW} /$ season $)$, 


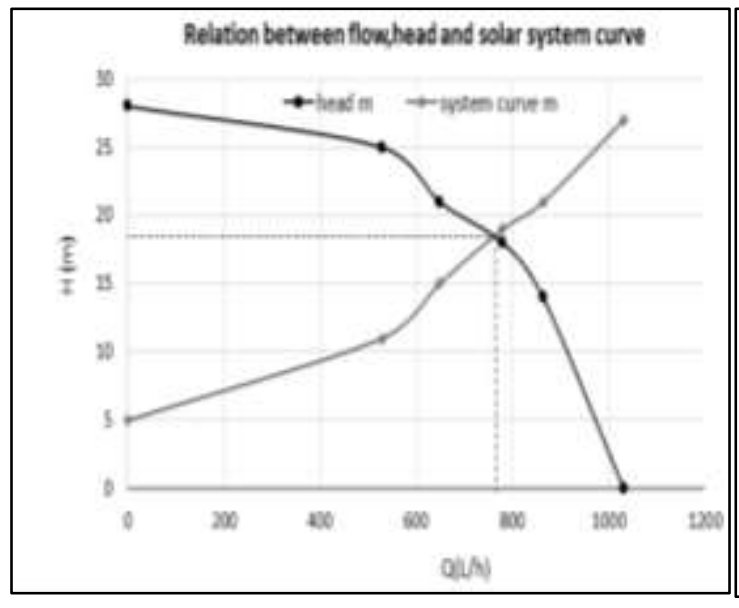

Solar pump

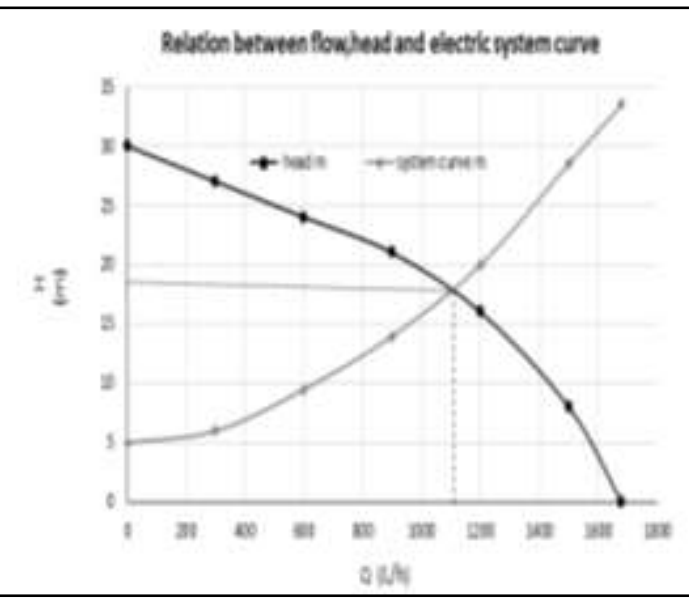

Electric pump

Fig 8. (Q-H) for Solar and electric Pumps in site

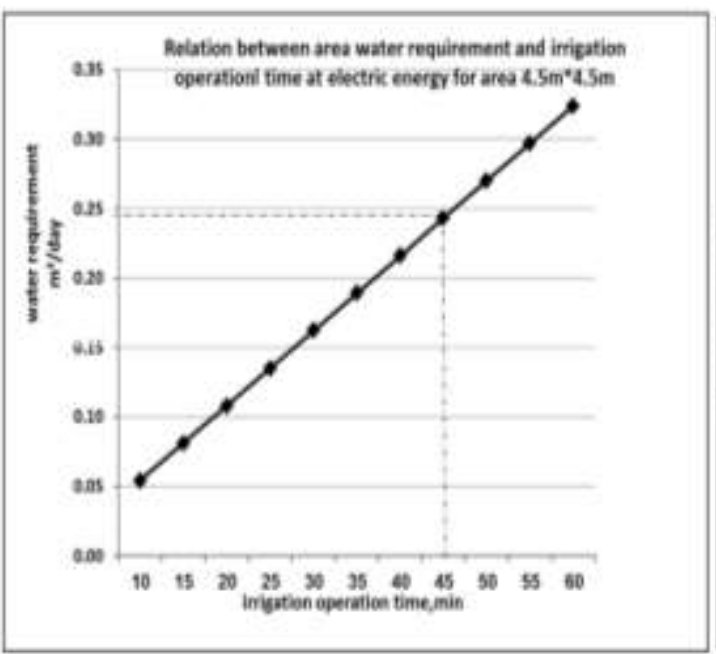

Solar pump

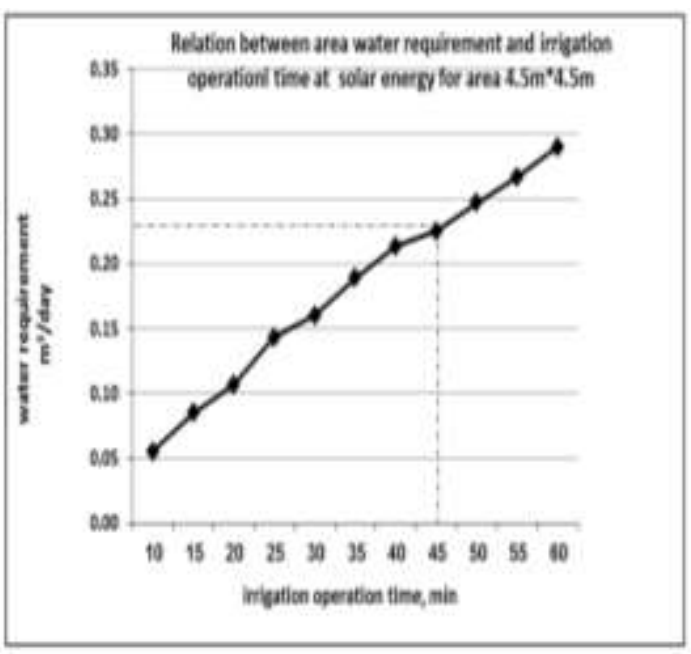

Electric pump

Fig 9. The capacity of water requirement landscape plot area at different operation times 


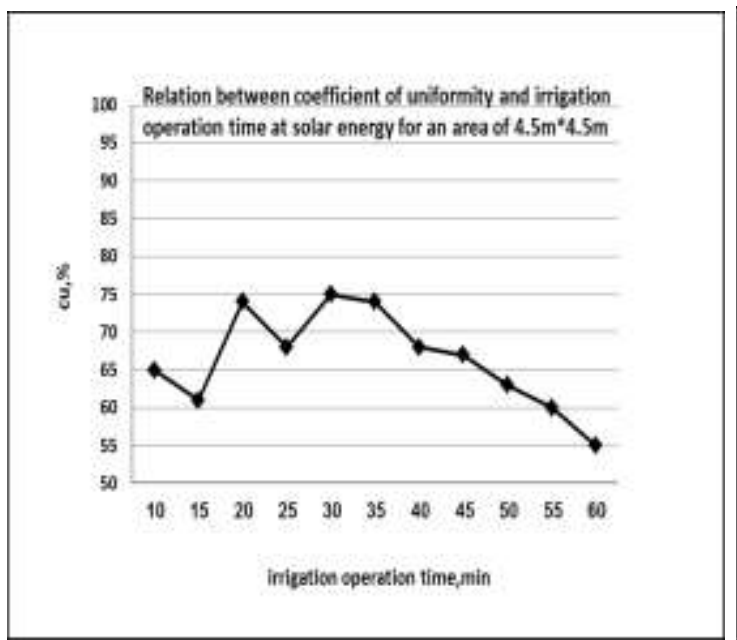

Solar pump

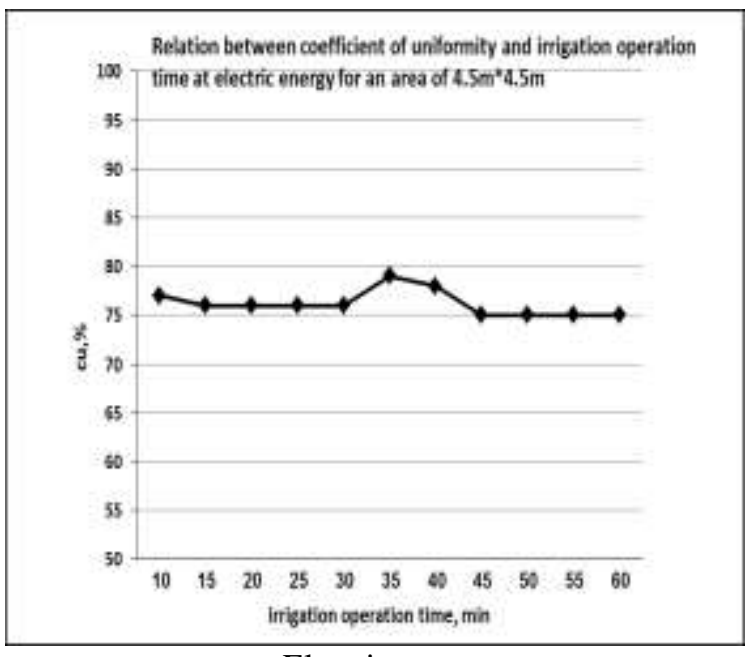

Electric pump

Fig 10. The relation between the uniformity coefficient at different operation irrigation times

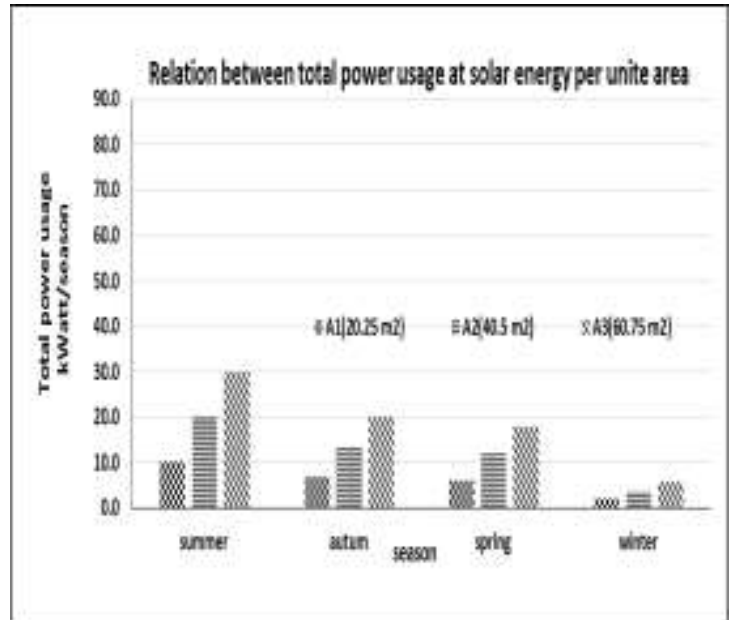

Solar pump

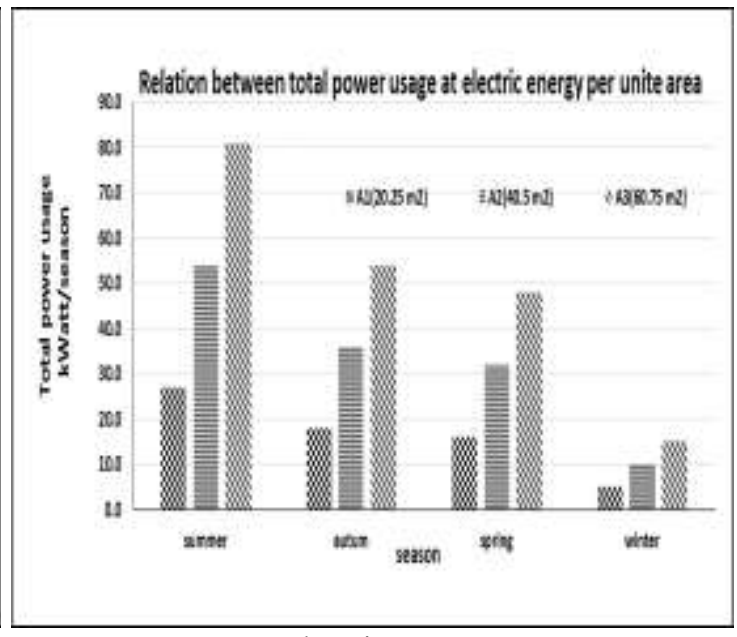

Electric pump

Fig 11. The relation between consumptive total power usages for a landscaped plot area per season under solar and electric energy 
while the lowest power usage was during winter at a value of ( $5 \mathrm{~kW} / \mathrm{season})$, the change in the readings was because of the difference of water discharge during different seasons, as the water requirements increase at summer and decrease during winter.

After relating the results of each system to the other, the energy-saving reached (63\%) at solar energy operation rather than the electric energy operation, at summer season, as the operating power for the solar pump motor was $144 \mathrm{~W} / \mathrm{h}$, while the operating power for the electric pump motor was $375 \mathrm{~W} / \mathrm{h}$.

\subsection{The relation between consumptive total water usages for a landscape plot area per season under solar and electric energy}

Data illustrated in Fig 12 showed that the highest water consumption for the solar pump was during summer at a value of $\left(27 \mathrm{~m}^{3} / \mathrm{sea}-\right.$ son), while the lowest water consumption was during winter at a value of $\left(5 \mathrm{~m}^{3} / \mathrm{season}\right)$.

Also, the highest water consumption for the electric pump was during summer at a value of $\left(29.2 \mathrm{~m}^{3} / \mathrm{season}\right)$, while the lowest water consumption was during winter at a value of $\left(5.4 \mathrm{~m}^{3} /\right.$ season $)$, the change in the readings was because of the difference in water discharge during different seasons for a plot area of $\left(20.25 \mathrm{~m}^{2}\right)$, as the water requirements increase at summer and decrease during winter.

After relating the results of each system to the other, the water-saving reached (7\%) at solar energy operation rather than the electric energy operation, during the summer season.

\subsection{The relation between water consump- tion used for turf per month in site}

Fig 13 represents the relation of water consumption in $\mathrm{m}^{3} / \mathrm{season}$ for the turf per month, depending on the average $\mathrm{ET}_{\mathrm{o}}(\mathrm{mm} /$ day $)$ readings during the months of the experiments which were obtained from Central Laboratory for Agricultural Climate (CLAC), The minimum value was on January at a value of (972 $\mathrm{L} / \mathrm{m}^{2} /$ month $)$ at $\mathrm{ET}_{\mathrm{o}}$ value of $(1.4 \mathrm{~mm} /$ day $)$, while the maximum value was on August at a value of $\left(5554 \mathrm{~L} / \mathrm{m}^{2} / \mathrm{month}\right)$ at $\mathrm{ET}_{\mathrm{o}}$ value of (8 $\mathrm{mm} /$ day).

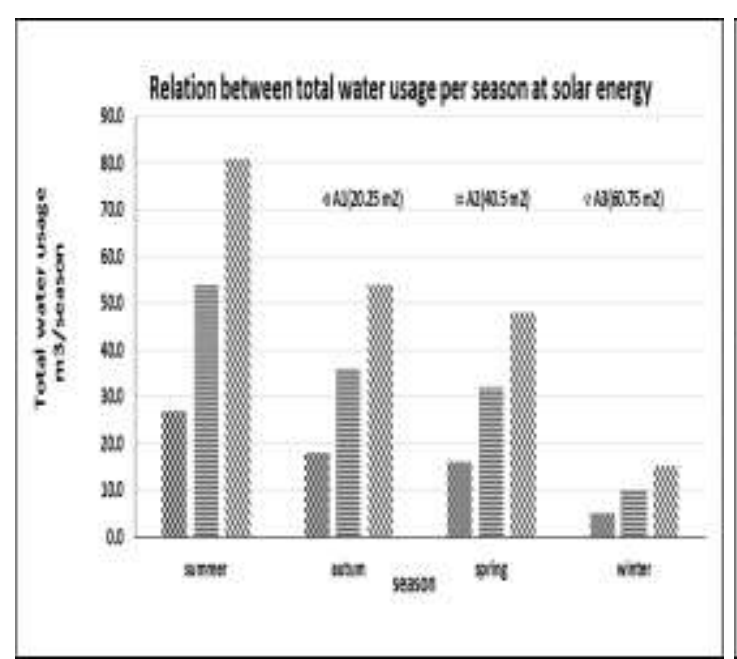

Solar pump

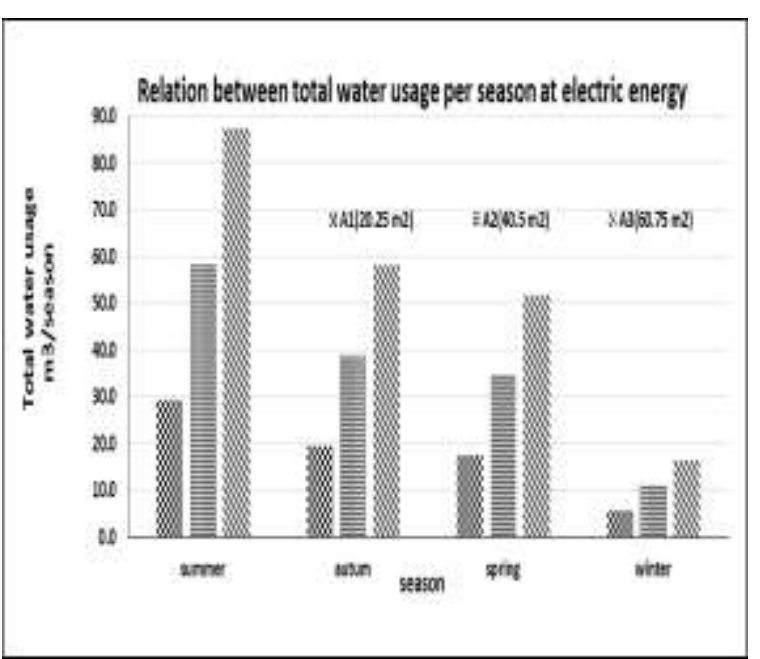

Electric pump

Fig 12. The relation between consumptive total water usages for a landscape plot area per season under solar and electric energy 


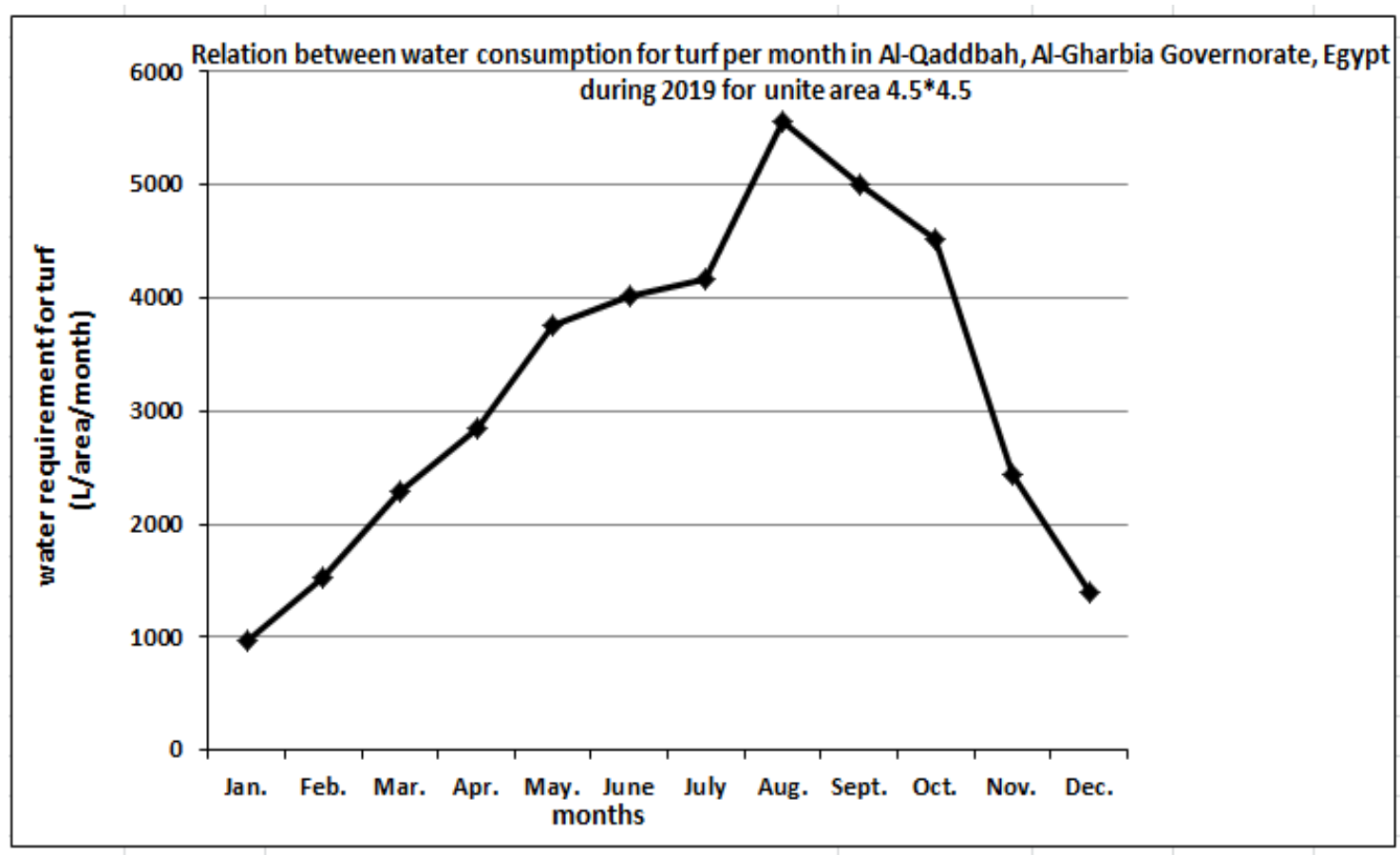

Fig 13. The relation between water consumption used for turf per month in site

3.7 Effect of the solar and electric energy system on the quality index for the landscape area

Fig 14 represents the turf quality index for the solar powered zone and electric powered zone, the best quality index including appearance and density were at electric system operation, as the solar-powered system had a variation in the operating pressure, which affected the uniformity coefficient of water on landscape area, so the landscape area was affected, while the electric powered system gave good quality index for plot area landscape it was stable in pressure.

\subsection{Effect of the solar energy system on the total cost for the irrigated landscape area}

Fig 15 showed that the least total cost per unite square meter for the landscape area was $351 \mathrm{~L} . \mathrm{E} / \mathrm{m}^{2} /$ year at $\mathrm{A}_{3}\left(60.75 \mathrm{~m}^{2}\right)$ each of a plot area equals $\left(20.25 \mathrm{~m}^{2}\right)$, which was irrigated on
3 cycles per day to obtain the optimum uniformity coefficient (75\%). Because of utilizing the optimum power operating from the photovoltaic cells per day.

Landscape area $\mathrm{A}_{3}\left(60.75 \mathrm{~m}^{2}\right)$ was less than $\mathrm{A}_{1}\left(20.25 \mathrm{~m}^{2}\right), \mathrm{A}_{2}\left(40.5 \mathrm{~m}^{2}\right)$, in annual total cost by $(47.6 \%-12.5 \%)$, respectively.

Landscape area $\mathrm{A}_{4}\left(81 \mathrm{~m}^{2}\right)$ had less in annual total cost than $\mathrm{A}_{3}$ by $5 \%$, but it was less in the uniformity coefficient for turf as it reached $45 \%$. The annual total cost decreased and the uniformity coefficient decreased as well which was reflected on the quality of the landscape area.

3.9 Effect of battery operating cycle on the uniformity coefficient spray for the landscape plot area

Fig 16 showed that when operating the solar batteries at full charge 3 - 4 times for a plot area of $\left(20.25 \mathrm{~m}^{2}\right)$, the hydraulic power obtained was (17.86 - 26.74 Watt) and the 
sprayer radius was $(5.3-5.8 \mathrm{~m})$, at an average pressure of $(1.9-2.5 \mathrm{bar})$, which gave the best uniformity coefficient irrigating the landscape area, meanwhile operating the same unite area $\left(20.25 \mathrm{~m}^{2}\right)$ with partially charged solar batteries, the hydraulic power obtained was (34.97$43.75 \mathrm{~W})$ with sprayer radius of $(3-5.2 \mathrm{~m})$, at an average pressure of (1.3 - 1.8 bar), giving the least uniformity coefficient irrigating the landscape area, so it was preferred to operate the solar batteries for the 3 cycles per day for $\left(\mathrm{A}_{3} 60.75 \mathrm{~m}^{2}\right)$ where each plot area was $(20.25$ $\mathrm{m}^{2}$ ) to achieve the optimum uniformity coefficient.

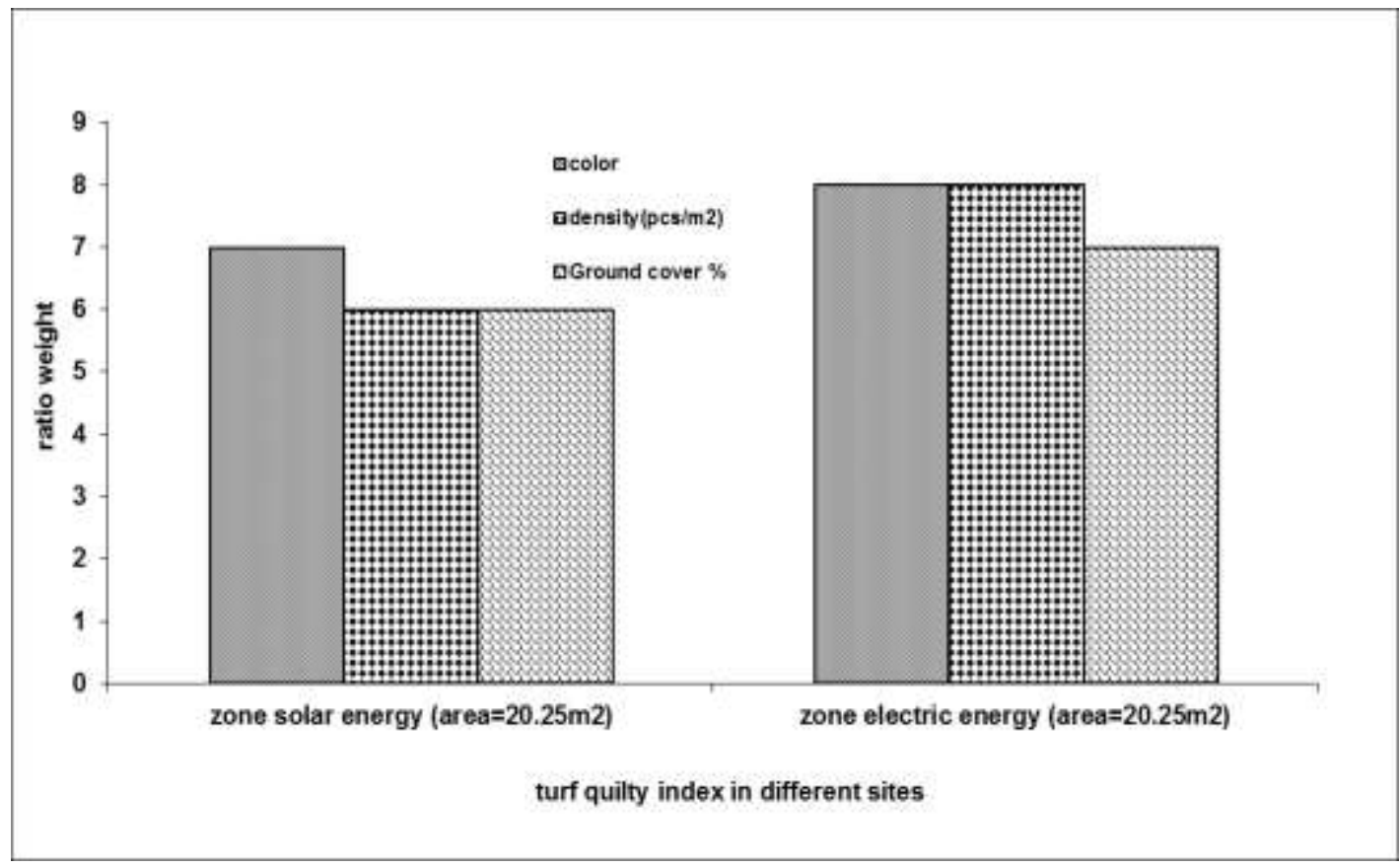

Fig 14. Effect of the solar and electric energy system on the quality index

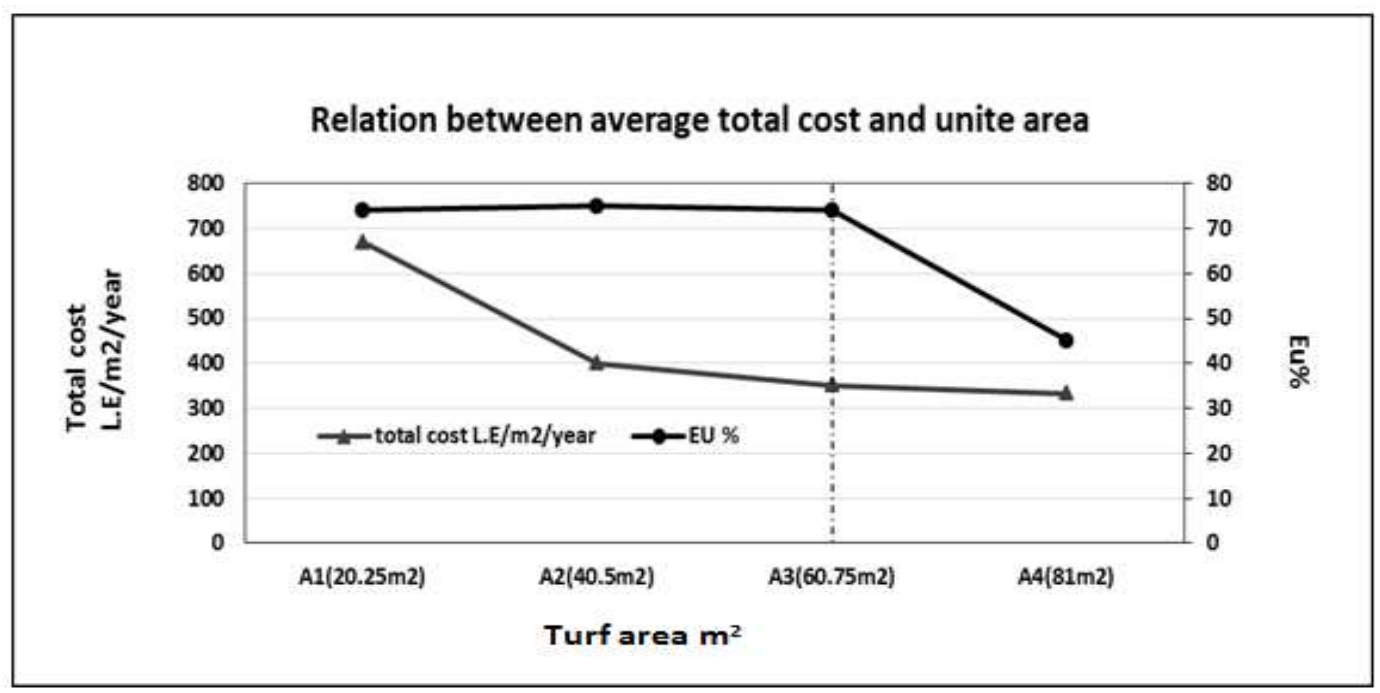

Fig 15. Effect of the solar and electric energy system on the total cost 


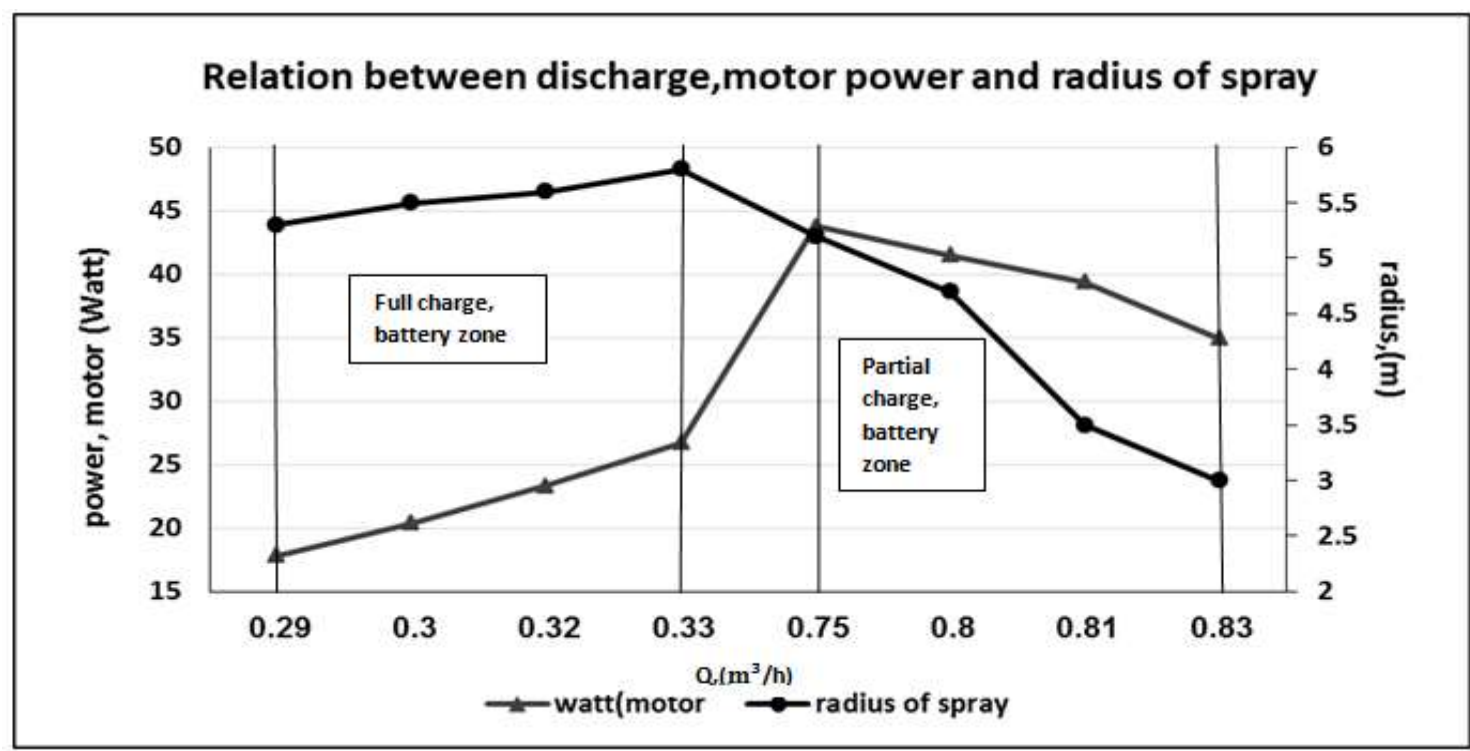

Fig. 16. Effect of battery operating cycle on the uniformity coefficient spray

\section{Conclusion}

Depending on the circumstances of this research. At solar energy powered system, it should be operated for a time interval of (10 $30 \mathrm{~min}$ ) to achieve the optimum uniformity coefficient, while at electric energy powered system it should be operated for a time interval of (10 - $40 \mathrm{~min})$ to achieve the optimum coefficient, it is preferred to operate using solar energy in the summer season rather than the electric system as it helps with the energy saving up to $(63 \%)$, while it is recommended to operate an area of $\left(\mathrm{A}_{3} 60.75 \mathrm{~m}^{2}\right)$ each of a plot area equals $\left(20.25 \mathrm{~m}^{2}\right)$ on three cycles per day depending on operating the solar batteries at full charge 3 - 4 times to achieve the optimum uniformity coefficient $(75 \%)$, and to achieve the least total cost per unit square meter for the landscape area which was $351 \mathrm{~L} . \mathrm{E} / \mathrm{m}^{2} /$ year. The turf quality index (color, density, ground cover) gave a high degree, using electric motor compared with solar motor, this was a result of the pressure stability in electric motors.

\section{References}

Awady, MN; Vis, EG; Kumar, R; Mitra, S (2003) Distribution uniformity from pop-up sprinklers and landscape water-saving. Misr $J$ Ag. Eng, 20, 4, 181-194.

Bahgat, G (2013) Egypt's Energy Outlook: Opportunities and Challenges. Mediterranean Quarterly, 24, 1-32.

Comsan, MNH (2010) Solar Energy Perspectives in Egypt. Environmental Physics Conference, 5, 10-14 Mar, Hurghada, Egypt, 1-11.

Costello, LR; Matheny, NP; Clark, JR (1993) Estimating water requirements of landscape plantings, the landscape coefficient method, Crop. Ext., U.C. Division of Agriculture and Natural Resources, Leaflet, 21493, 11-12.

El-Gindy, AM (2007) On-farm irrigation systems and technologies, $1^{\text {st }}$ ed, Police Press for Publishing and Distribution, Cairo, Egypt, $p$ 376. 

Irrigation System

Gopal, C; Mohanraj, M; Chandramohan, P; Chandrasekar, P (2013) Renewable energy source water pumping systems - A literature review. Renewable and Sustainable Energy Reviews, 25, 351-370.

IA (2009) Water sense Commercial and Institutional Sector Comments, $\mathrm{p} 2$.

Karmeli, D (1978) Estimating sprinkler distribution pattern using linear regression. Transactions of the ASAE, 21, 4, 682-686.

Khaseeva, KA (2013) Evaluation of turf quality for cool-season species and cultivars. Polythematic Online Scientific Journal of Kuban State Agrarian University, Russia, 92, 8, 115129.
Malak, I (2016) Pumping Water Using Solar Energy for Irrigation, Al Akhawayn University Report, Ifrane, Morocco, p 16.

Razavi, H; Faller, T; Negash, E; Ounalli, A; Bellot, Z (2012) Clean energy development in Egypt. African Development Bank. Tunis, Tunisia, 7.

Topak, R; Suheri, S; Ciftci, N; Acar, B (2005) Performance evaluation of sprinkler irrigation in a semi-arid area. Pakistan Journal of Biological Sciences, 8, 1, 97-103.

USEIA (2014) Country Analysis Brief, Egypt, issue brief. 


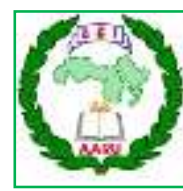

مجلة اتحاد الجامعات العربية للعلوم الزراعية، جامعة عين شمس، القاهرة، مصر

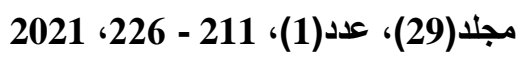

تقييم أداء مضخة شمسية لنظام ري المسطحات خضراء

رفيده حاتم محمد راشد الاحول1" - محمود محمد حجازى1 - محمد هويدي2 - أسامة محمد أحمد بدير1

1- قسم الهنسة الزراعية - كلية الزراعة - جامعة عين شمس - ص.ب 68 - حدائق شبرا 11241 - القاهرة - مصر

2- قسم البساتين - كلية الزراعة - جامعة عين شمس - ص.ب 68 - حدائق شبرا 11241 - القاهرة - مصر

* Corresponding author: rofida@agr.asu.edu.egorcid.org/0000-0002

60 دقيقة) إنخفض معامل إنتظامية توزيع المياه، بينما

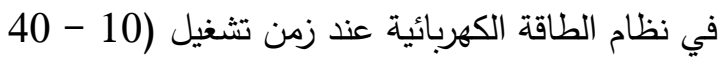

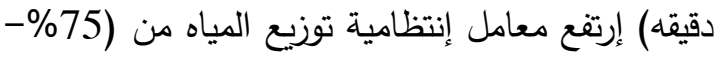

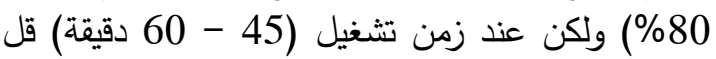
معامل إنتظامية توزيع المياه إلى (75) (75) (45). وتم توفير الطاقة المستهلكة بقيمة (63\%) عندام إستخدام نظام الطاقة الثمسية بالمقارنة مع إستخدام نظام الطاقة الكهربائية في فصل الصيف.كانت أقل تكاليف كلية سنوية هي (351 ج/سنة) وذلك عند مساحة (60.75

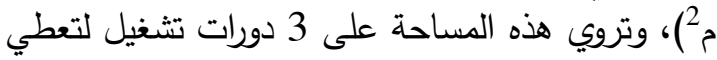
أفضل معامل لإنتظامية التوزيع للمياه (75 (75). تشغيل بطاريات الخلايا الشمسية في حاله الثحن التام التام

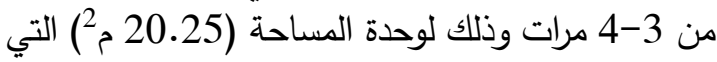

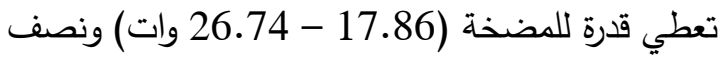
قطر الرشاش (5.3 - 5.8 م) عند متوسط لفنغط تشغيل

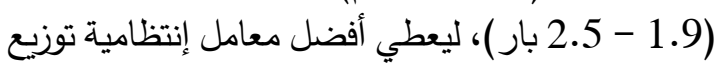

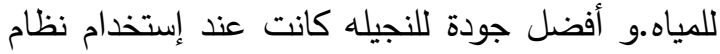
الطاقة الكهربائية بالمقارنة مع نظام الطاقة الثمسية.

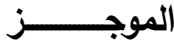

أجريت التجارب العملية فى مزرعه خاصه بالقضابة

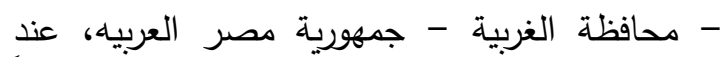

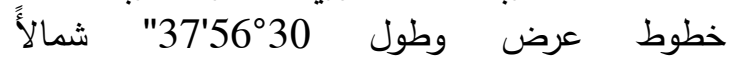
و و

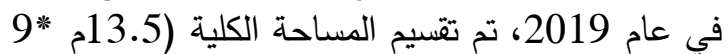

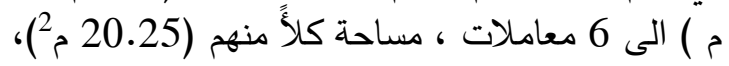
حيث تم تشغيل مساحة ثلاث مربعات بإستخدام نظام الطاقة الثمسية بينما تم تشغيل الثثلاث مربعات الأخرى

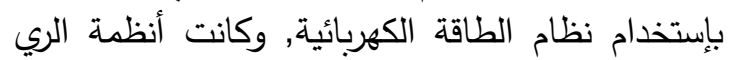
متماثلة (4 رشاشات (90)

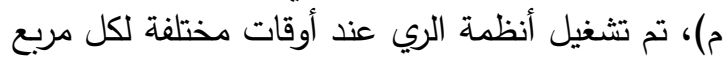

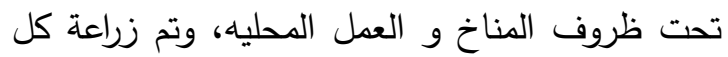

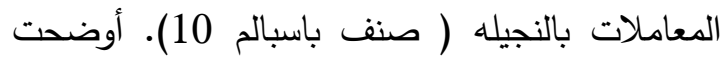

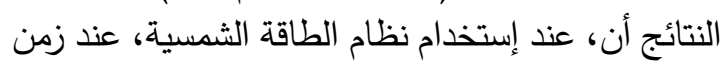
تشغيل (10 - 30 دقيقة) إرتفع معامل إنتظامية توزيع المياه من (65\%- 75\%)، وعند زمن تشغيل (40 - (40 - مقيعة) 